\title{
Cystic brain metastases radiologically simulating neurocysticercosis
}

\author{
Metástases císticas cerebrais simulando neurocisticercose radiologicamente
}

\author{
Charlene Troiani', Carla Cristina Barbosa Lopes", Carlos Antônio Scardovelli'", Gisele Alborghetti Nai'l' \\ Faculdade de Medicina da Universidade do Oeste Paulista (Unoeste), Presidente Prudente, São Paulo, Brazil
}

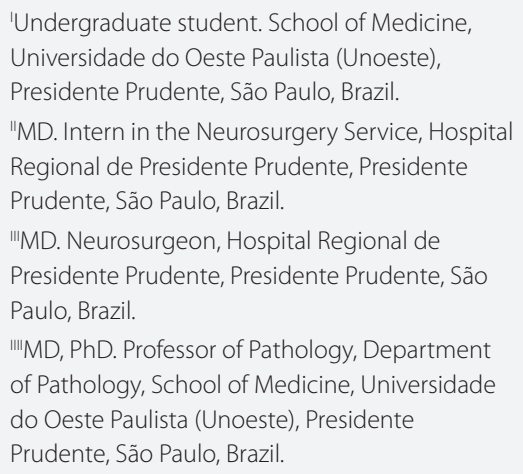

Undergraduate student. School of Medicine, Universidade do Oeste Paulista (Unoeste), Presidente Prudente, São Paulo, Brazil. "MD. Intern in the Neurosurgery Service, Hospital Regional de Presidente Prudente, Presidente Prudente, São Paulo, Brazil.

"'MD. Neurosurgeon, Hospital Regional de Presidente Prudente, Presidente Prudente, São Paulo, Brazil.

'I'MD, PhD. Professor of Pathology, Department of Pathology, School of Medicine, Universidade do Oeste Paulista (Unoeste), Presidente

Prudente, São Paulo, Brazil.

\section{KEY WORDS:}

Neoplasm metastasis.

Neurocysticercosis.

Cysticercus.

Brain diseases.

Magnetic resonance imaging.

\section{PALAVRAS-CHAVE:}

Metástase neoplásica.

Neurocisticercose.

Cisticerco.

Doenças cerebrais.

Imagem por ressonância magnética.

\begin{abstract}
CONTEXT: Brain metastases are common complications of cancer. Magnetic resonance imaging (MRI), the main diagnostic imaging method in these cases, rarely shows cystic images.

CASE REPORT: The patient was a 45-year-old woman who had had severe headache for a month that was refractory to medication, and had previously had breast cancer, which had been treated. The MRI showed the criteria for neurocysticercosis. Since there was no improvement with clinical treatment, we chose to excise the lesions. Histopathological analysis showed an epithelioid malignant neoplasm.

CONCLUSION: From immunohistochemical analysis, it was concluded that this was a metastasis of breast carcinoma. Even when the MRI is not characteristic of cerebral metastasis, this hypothesis needs to be ruled out in patients with a previous history of cancer.
\end{abstract}

\section{RESUMO}

CONTEXTO: Metástases cerebrais são complicações comuns do câncer. A ressonância nuclear magnética (RNM), principal método de diagnóstico por imagem nesses casos, mostra raramente imagens císticas. RELATO DO CASO: A paciente era uma mulher de 45 anos de idade, com cefaleia intensa há um mês, refratária à medicação, e câncer de mama tratado previamente. A RNM apresentava critérios diagnósticos para neurocisticercose. Como não apresentou melhora com tratamento clínico, optou-se pela exérese das lesões. O histopatológico mostrou neoplasia maligna epitelioide.

CONCLUSÃO: A imunoistoquímica revelou metástase de carcinoma da mama. Mesmo quando a RNM não é característica de metástase cerebral, esta hipótese precisa ser afastada em pacientes com história prévia de câncer.

\section{INTRODUCTION}

Brain metastases are common complications of cancer, and show increasing incidence. They may present clinically as headache, seizures or loss of cognitive or motor function depending on the location of the lesions. ${ }^{1}$ Cancers of the breast, lung, kidney, gastrointestinal tract and skin are the commonest causes of cerebral metastases. ${ }^{1}$

Magnetic resonance imaging (MRI) is the main diagnostic imaging method. However, metastases rarely show multiple cystic images on MRI. ${ }^{2}$

The World Health Organization (WHO) considers that neurocysticercosis is the commonest parasitic disease of the brain; its main manifestation is seizure. ${ }^{3,4}$ The prevalence of neurocysticercosis in Brazil is unknown because of the absence of mandatory reporting in most states. The seropositivity reaction rate in Brazil is $2.3 \%$, representing $0.3 \%$ of all hospitalizations. ${ }^{5} \mathrm{Neu}-$ rocysticercosis has been reported in most Brazilian states, with highest prevalence in Paraná, São Paulo, Minas Gerais and Goiás. The costs due to neurocysticercosis treatment and complications in Brazil may reach up to US\$ 85 million. ${ }^{6}$

We report an unusual case of cystic brain lesions with a radiological diagnosis of neurocysticercosis, but a pathological diagnosis of brain metastases. This case shows the importance of valuing the patient's clinical history in the differential diagnosis of multiple brain lesions.

\section{CASE REPORT}

A 45-year-old female was admitted to the Regional Hospital in Presidente Prudente, State of São Paulo, with a complaint of severe headache for a month that was refractory to medication. 
She had a history of breast cancer that had been treated with radiotherapy three years before the time of the admission described here.

Computed tomography (CT) showed several hypodense lesions in cerebral parenchyma. MRI showed cystic lesions with an internal nodular structure that was similar to a scolex, thus suggesting the diagnosis of neurocysticercosis. The lesions also had contrast enhancement on the periphery of the cyst that was more intense in the region of mural nodules (Figure 1).

The patient was treated with albendazole for five days, but without improvement. She then underwent surgery to resect the lesions (Figure 2A).

The pathological examination revealed an epithelioid malignant neoplasm (Figure 2B). Immunohistochemical analysis showed positivity for pan-cytokeratin markers (AE1/AE3) and cytokeratin 7 (CK7) and negativity for cytokeratin 20 (CK20), S-100 protein, estrogen receptor and thyroid transcription factor-1 (TTF-1). From this, the conclusion was a diagnosis of metastatic breast cancer.

The patient underwent radiotherapy, but without improvement. She was admitted to the hospital sometimes with severe headache and vomiting and cerebral edema, but missed the follow-up after one year.

\section{DISCUSSION}

Cysts are common findings on MRI and CT brain imaging. Their histopathological spectrum is broad, and differentiation of these cysts on the basis of imaging findings alone can be problematic. ${ }^{7,8}$

Neurocysticercosis is the most common parasitic disease of the central nervous system (CNS) and should be considered to be a differential diagnosis of brain metastases, especially in patients in endemic countries, because of the similarity of clinical manifestations. ${ }^{9}$ We searched in the Lilacs (Literatura LatinoAmericana e do Caribe em Ciências da Saúde), IBECS (Índice Bibliográfico Espanhol de Ciências de Saúde), Scirus, Embase (Excerpta Medica database) and Medline databases, using MeSH (Medical Subject Headings), and only one case report related to the differential diagnosis between neurocysticercosis and brain metastasis $^{9}$ (Table 1).

Neurocysticercosis occurs in $60 \%$ to $90 \%$ of all cases of systemic cysticercosis. ${ }^{7}$ A typical presentation of cerebral cysticercosis may mimic glioma, metastasis or cerebral abscess, or vice versa. ${ }^{10}$ Most neurocysticercosis cysts are found in the subarachnoid spaces: typically the basal cisterns and deep within the sulci. ${ }^{7}$ A smooth thin-walled cyst on MRI images typifies the early vesicular stage of neurocysticercosis. Edema and contrast enhancement are rare. A mural nodule is often present that represents the viable larval scolex, i.e. the "cyst with a dot" appearance. ${ }^{3,7,9}$ Usually, the lesions are $<20 \mathrm{~mm}$ in diameter. ${ }^{11}$ Identification of brain vesicles with scolex is pathognomonic of neurocysticercosis, while inflammatory changes around the lesion indicate the degenerative process of the parasite. ${ }^{2}$ About $15 \%$ of patients with neurocysticercosis have a unique cysticercus in the CNS. ${ }^{3}$ In the case reported here, the multiple lesion-like "cyst with a dot" appearance on MRI suggested the diagnosis of neurocysticercosis. One clue in this case could be the contrast enhancement around all the lesions, which is not seen in neurocysticercosis but occurs in brain metastases. Even in countries where neurocistecercosis is endemic and MRI abnormalities were suggestive of scolex, brain metastasis must be ruled out in the presence of contrast enhancement around the lesions, especially in patients with previous history of cancer.

Establishing the diagnosis of a brain tumor is not always a straightforward process. Many neoplastic neurological diseases can mimic brain neoplasms on neuroimaging or on histological examination, including multiple sclerosis, stroke, pyogenic abscess, toxoplasmosis, tuberculosis, cysticercosis, fungal infection, syphilis, sarcoidosis, Behçet disease, radiation necrosis, venous thrombosis, and others. ${ }^{12}$

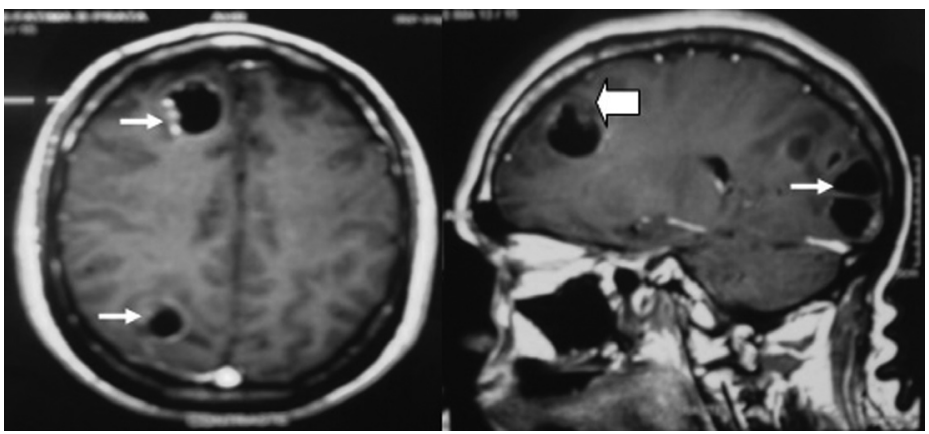

Figure 1. Magnetic resonance imaging (MRI) showing rounded cysts characterized by low signal on T1-weighted sequences and hyperintense on T2-weighted sequences (thin arrows). Some cysts have small nodules on their wall (large arrow). Note the contrast enhancement on the periphery of the cyst and more intensely in the region of mural nodules.

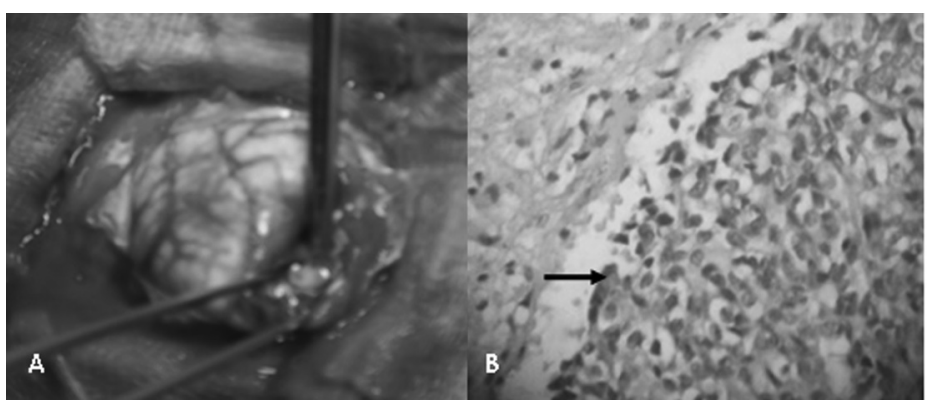

Figure 2. (A) Surgical resection of brain lesion. (B) Optical microscopy showing epithelioid malignant neoplasm (arrow) (hematoxylin and eosin, $250 \mathrm{x}$ ). 
Primary brain tumors are rarely multiple. Pilocytic astrocytoma, ganglion cell tumors, ependymomas, hemangioblastomas and pleomorphic xanthoastrocytoma are some of the primary brain tumors that can be cystic. Of these, hemangioblastomas may be epithelioid. ${ }^{1}$

To determine whether a tumor is primary or not, and the primary site of metastatic tumors, immunohistochemical analysis can be used, with specific markers for each tissue and cell. ${ }^{6}$ The use of multiple markers may increase the sensitivity, speci-

Table 1. Results from the review of the medical databases, using descriptors relating to the differential diagnosis of this case

\begin{tabular}{|c|c|c|}
\hline Database & Search strategy & Results \\
\hline Medline & & $\begin{array}{l}374 \text { case reports } \\
95 \text { retrospective studies } \\
72 \text { incidence studies } \\
56 \text { prevalence studies } \\
12 \text { cohort studies } \\
37 \text { case-control studies } \\
3 \text { editorials/communications } \\
5 \text { narrative reviews }\end{array}$ \\
\hline Lilacs & & $\begin{array}{l}66 \text { case reports } \\
134 \text { retrospective studies } \\
19 \text { incidence studies } \\
19 \text { prevalence studies } \\
10 \text { case-control studies } \\
6 \text { randomized controlled trials } \\
10 \text { narrative reviews }\end{array}$ \\
\hline IBECS & "Neurocysticercosis" & $\begin{array}{l}10 \text { case reports } \\
41 \text { retrospective studies } \\
1 \text { incidence study } \\
1 \text { prevalence study } \\
2 \text { narrative reviews }\end{array}$ \\
\hline Scirus & & $\begin{array}{l}1242 \text { case reports } \\
297 \text { retrospective studies } \\
149 \text { incidence studies } \\
134 \text { prevalence studies } \\
17 \text { cohort studies } \\
43 \text { case-control studies } \\
7 \text { editorials/communications } \\
13 \text { narrative reviews }\end{array}$ \\
\hline Embase & & $\begin{array}{l}69 \text { case reports } \\
153 \text { retrospective studies } \\
117 \text { letters } \\
17 \text { editorials/communications } \\
135 \text { narrative reviews }\end{array}$ \\
\hline Medline & & $\begin{array}{l}1 \text { case report (Coulibaly et al. }{ }^{9} \text { ) } \\
2 \text { retrospective studies } \\
1 \text { incidence study } \\
1 \text { case-control study }\end{array}$ \\
\hline Scirus & $\begin{array}{l}\text { "Neurocysticercosis" } \\
\text { and "brain } \\
\text { metastasis" }\end{array}$ & $\begin{array}{l}34 \text { case reports } \\
39 \text { retrospective studies } \\
10 \text { incidence studies } \\
7 \text { prevalence studies } \\
5 \text { case-control studies } \\
3 \text { narrative reviews }\end{array}$ \\
\hline Embase & & $\begin{array}{l}4 \text { retrospective studies } \\
1 \text { letter }\end{array}$ \\
\hline
\end{tabular}

ficity and positive predictive value in predicting the tissue of tumor origin. ${ }^{13}$

Metastatic adenocarcinoma of unknown primary site is a common clinical problem. The use of cytokeratin 20 (CK20) and 7 (CK7) can assist in identifying primary sites in this situation. CK20 positivity indicates only adenocarcinoma metastasis of many organs. CK7 negativity is consistent with metastatic adenocarcinoma of the lung, ovaries, liver or serous membranes. ${ }^{14}$

Table 1 - Continuation

\begin{tabular}{|c|c|c|}
\hline Database & Search strategy & Results \\
\hline \multirow[t]{4}{*}{ Medline } & \multirow{15}{*}{$\begin{array}{c}\text { "Brain metastasis" } \\
\text { and "cyst" }\end{array}$} & 10 case reports \\
\hline & & 77 retrospective studies \\
\hline & & 1 incidence study \\
\hline & & 5 narrative reviews \\
\hline \multirow[t]{2}{*}{ Lilacs } & & 1 case report \\
\hline & & 1 review \\
\hline \multirow[t]{7}{*}{ Scirus } & & 1751 case reports \\
\hline & & 430 retrospective studies \\
\hline & & 297 incidence studies \\
\hline & & 238 prevalence studies \\
\hline & & 39 cohort studies \\
\hline & & 72 case-control studies \\
\hline & & 27 narrative reviews \\
\hline \multirow[t]{2}{*}{ Embase } & & 1 case report \\
\hline & & 1 retrospective study \\
\hline \multirow[t]{7}{*}{ Medline } & & 217 case reports \\
\hline & & 336 retrospective studies \\
\hline & & 70 incidence studies \\
\hline & & 6 prevalence studies \\
\hline & & 20 cohort studies \\
\hline & & 8 case-control studies \\
\hline & & 10 narrative reviews \\
\hline \multirow[t]{3}{*}{ Lilacs } & & 5 case reports \\
\hline & & 4 retrospective studies \\
\hline & & 2 incidence studies \\
\hline \multirow[t]{2}{*}{ IBECS } & & 1 case report \\
\hline & & 2 retrospective studies \\
\hline \multirow[t]{8}{*}{ Scirus } & & 9564 case reports \\
\hline & "Brain metastasis" & 2244 retrospective studies \\
\hline & and "breast cancer" & 1692 incidence studies \\
\hline & & 1308 prevalence studies \\
\hline & & 572 cohort studies \\
\hline & & 329 case-control studies \\
\hline & & 8 editorials/communications \\
\hline & & 135 narrative reviews \\
\hline \multirow[t]{8}{*}{ Embase } & & 90 case reports \\
\hline & & 210 retrospective studies \\
\hline & & 56 incidence studies \\
\hline & & 51 cohort studies \\
\hline & & 39 case-control studies \\
\hline & & 17 letters \\
\hline & & 4 editorials/communications \\
\hline & & 68 narrative reviews \\
\hline
\end{tabular}

*Using the same search strategy in Lilacs and IBECS database, no results were found; ${ }^{+}$Using the same search strategy in IBECS database, no results were found. 
Astrocytic neoplasms and hemangioblastomas (neoplasms of vascular origin) do not test positive for cytokeratin (epithelial cell marker). Negativity for the TTF-1 marker rules out the possibility of thyroid and primary neuroendocrine lung tumor as the primary site. Cytokeratin 7 positivity and cytokeratin 20 negativity promote the breast as the primary site. Negativity for estrogen receptors does not rule out this possibility, since many breast tumors are not positive for hormonal receptors, ${ }^{15}$ as occurred in this case.

In brain metastases, intracranial hypertension and motor deficits are common. The most sensitive methods for diagnosis are CT and MRI when there is no meningeal involvement. In these cases, examination of cerebrospinal fluid (CSF) may be more effective. The use of tumor markers such as CEA (carcinoembryonic antigen) and CA-15.3 (often elevated in breast carcinomas) in routine CSF examinations has shown promising results, especially in relation to leptomeningeal metastases. ${ }^{16}$

The survival with a single brain metastasis is longer than with multiple brain metastases, and hence the treatment in such cases consists of immediate surgery, when feasible, and optimal adjuvant therapy. ${ }^{17}$ In our case, although the patient has undergone radiotherapy, there was no clinical improvement, probably due to the presence of multiple brain lesions.

Distinguishing non-neoplastic causes from neoplastic lesions is extremely important, because misdiagnosis can lead to unwarranted neurosurgery and exposure to toxic chemotherapy or potentially harmful brain irradiation. Diligent clinical evaluation and a battery of tests are required, for a definitive diagnosis to be made. ${ }^{11}$ Newer advanced diagnostic techniques, such as diffusion-weighted MRI, perfusion-weighted MRI, magnetic resonance spectroscopy, single-photon emission tomography and positron emission tomography, as well as new tools for histological examination, such as immunohistochemical and molecular genetic analysis can help in establishing the diagnosis. ${ }^{11,12,18-20}$

\section{CONCLUSION}

Even in cases in which MRI is not characteristic of cerebral metastasis, this hypothesis needs to be excluded when there is no improvement with clinical treatment and in patients with a previous history of cancer, especially breast cancer, which is a common cause of brain metastasis.

\section{REFERENCES}

1. Burger PC, Scheithauer BW. Atlas of tumor pathology. Tumors of the central nervous system. Washington: American Registry of Pathology; 1993.
2. do Amaral LL, Ferreira RM, da Rocha AJ, Ferreira NP. Neurocysticercosis: evaluation with advanced magnetic resonance techniques and atypical forms. Top Magn Reson Imaging. 2005;16(2):127-44.

3. Machado LR. Diagnóstico da neurocisticercose: uma questão fechada? [The diagnosis of neurocysticercosis: a closed question?] Arq Neuropsiquiatr. 2010;68(1):1-2.

4. Colli BO, Carlotti CG Jr, Assirati JA Jr, et al. Surgical treatment of cerebral cysticercosis: long-term results and prognostic factors. Neurosurg Focus. 2002;12(6):e3.

5. Agapejev S. Aspectos clínico-epidemiológicos da neurocisticercose no Brasil: análise crítica [Clinical and epidemiological aspects of neurocysticercosis in Brazil: a critical approach]. Arq Neuropsiquiatr. 2003;61(3B):822-8.

6. Grazziotin AL, Fontalvo MC, Santos MBF, Monego F, Grazziotin AL. Perfil epidemiológico de pacientes com neurocisticercose diagnosticados por tomografia computadorizada em Curitiba, Brazil [Epidemiologic pattern of patients with neurocysticercosis diagnosed by computed tomography in Curitiba, Brazil]. Arq Neuropsiquiatr. 2010;68(2):269-72.

7. Osborn AG, Preece MT. Intracranial cysts: radiologic-pathologic correlation and imaging approach. Radiology. 2006;239(3):650-64.

8. Mishra AM, Gupta RK, Jaggi RS, et al. Role of diffusion-weighted imaging and in vivo proton magnetic resonance spectroscopy in the differential diagnosis of ring-enhancing intracranial cystic mass lesions. J Comput Assist Tomogr. 2004;28(4):540-7.

9. CoulibalyB,GautierG,FuentesS,RanqueS,BouvierC.Neurocysticercose cérébrale au stade de dégénérescence: diagnostic différentiel des métastases cérébrales [Degenerating neurocysticercosis cysts: differential diagnosis with cerebral metastasis]. Rev Neurol (Paris). 2008;164(11):948-52.

10. Tripathi RP, Gupta A, Gupta S, et al. Co-existence of dual intracranial pathology clinical relevance of proton MRS. Neurol India. 2000;48(4):365-9.

11. Garg RK, Sinha MK. Multiple ring-enhancing lesions of the brain. J Postgrad Med. 2010;56(4):307-16.

12. Omuro AM, Leite CC, Mokhtari K, Delattre JY. Pitfalls in the diagnosis of brain tumours. Lancet Neurol. 2006;5(11):937-48.

13. ParkSY,Kim BH, Kim JH, LeeS, Kang GH. Panels of immunohistochemical markers help determine primary sites of metastatic adenocarcinoma. Arch Pathol Lab Med. 2007;131(10):1561-7.

14. Tot T. Cytokeratins 20 and 7 as biomarkers: usefulness in discriminating primary from metastatic adenocarcinoma. Eur J Cancer. 2002;38(6):758-63.

15. Schwarz RE, Klimstra DS, Turnbull AD. Metastatic breast cancer masquerading as gastrointestinal primary. Am J Gastroenterol. 1998;93(1):111-4.

16. Machado AB, Machado AA, Barbuto JA, de Oliveira RM. Central nervous system metastases from breast carcinoma. A clinical 
and laboratorial study in 47 patients. Arq Neuropsiquiatr. 1998;56(2):188-92.

17. Ersahin M, Kilic K, Gögüsgeren MA, et al. Multiple brain metastases from malignant thymoma. J Clin Neurosci. 2007;14(11):1116-20.

18. Reddy JS, Mishra AM, Behari S, et al. The role of diffusion-weighted imaging in the differential diagnosis of intracranial cystic mass lesions: a report of 147 lesions. Surg Neurol. 2006;66(3):246-50; discussion 250-1.

19. Reich W, Schuchardt $V$, Hagen $T$, et al. Differential diagnosis of intracranial ring enhancing cystic mass lesions--role of diffusionweighted imaging (DWI) and diffusion-tensor imaging (DTI). Clin Neurol Neurosurg. 2010;112(3):218-25.

20. Nath $K$, Agarwal M, Ramola M, et al. Role of diffusion tensor imaging metrics and in vivo proton magnetic resonance spectroscopy in the differential diagnosis of cystic intracranial mass lesion. Magn Reson Imaging. 2009;27(2):198-206.

Sources of funding: None

Conflict of interest: None

Date of first submission: September 16, 2010

Last received: December 9, 2010

Accepted: February 21, 2011

\section{Address for correspondence:}

Gisele Alborghetti Nai

Departamento de Patologia da Universidade do Oeste Paulista (Unoeste)

Rua José Bongiovani, 700

Presidente Prudente (SP) — Brasil

CEP 19050-680

Tel. (+55 18) 3229-1059

Fax. (+55-18) 3229-1194

E-mail: patologia@unoeste.br 